\title{
ENZYMES ACTING ON GLUCOSAMINE PHOSPHATES *
}

\author{
By L. F. Leloir and C. E. Cardini \\ Instituto de Investigaciones Bioquimicas, Fundación Campomar \\ Buenos Aires, Argentina
}

Uridine disphosphate acetylglucosamine was first isolated from yeast ${ }^{1}$ and has been detected in mammalian liver 2345 and hen oviduct ${ }^{6}$ A specific pyrophosphorylase has been found 5 to transform it into uridine triphosphate and acetylglucosamine-I-phosphate, so that the latter is likely to be a normal metabolite in mammals. In order to make this ester available for enzymic studies, a chemical method for its synthesis has been developed, following a procedure inspired by that used by CoRI, CoRowick AND CORI ${ }^{7}$ for the preparation of glucose-I-phosphate.

Acetylglucosamine-1-phosphate was first tested with an enzyme Trom Neurospora and found ${ }^{8}$ to be converted to acetylglucosamine6-phosphate. This enzyme which is activated by the $1,6+$ disphosphates of glucose or acetylglucosamine has been studied by REIssig 9 . It has now been observed that similar changes are catalyzed by mammalian enzymes thus giving rise to acetylglucosamine-6-phosphate. This substance which has been previousty obtained by the enzymic acetylation of glucosamine 6-phosphate 810 has been found to be converted into fructose-6-phosphate by kidney enzymes. But the most unexpected finding was that it catalyses the enzymes transformation of glucosamine-6-phosphate into fructose6-phosphate and ammonia. Furthermore the latter reaction was found to be reversible so that it affords a possible route to hexosamine synthesis different from that found in Neurospora ${ }^{8}$ where glutamine is involved. Previous work on hexosamine metabolism has been reviewed by Dorfman 11 and Kent and WhiteHOUSE 12 .

* This investigation was supported in part by a rescarch grant (No. G 3442) from the National Institutes of Health, U. S. Public Health Service.
METHODS

Analytical

The following methods were used. Phosphate. Fiske and Subrarow 13, protein, Kunitz and McDonald 14; fructose, Roe 15: glucosamine, Blix 1ô; ammonia, ConWAy 17; for acetlyglucosamine a modification of the MORGan AND Elson method 18 was used with a standard of acetylglucosamine prepared as described by Rosfman and Ludowieg 19. With purified enzymes deproteinization was unnecessary. For acetylglucosamine -1-phosphate which does not give the test directlyproteins were precipitated with $5 \%$ trichloracetic acid. After centrifugation, $0.5 \mathrm{ml}$. of supernatant was heated 10 minutes at $100^{\circ} \mathrm{C}$ in orden to hydrolyze the phosphate group. After cooling, $0.15 \mathrm{ml}$ of $1 . M$ potassium borate was added and the procedure continued as described by Rfissic; et at 18 A larger amount of borate $(0.15$ instead of $0.1 \mathrm{ml})$ was used in order to neutralize the acid.

When it was necesary to distinguish free hexosamines from their phosphoric, esters (Table III) the latter were precipitated by adding zinc sulfate and barium hydroxide solutions as described by Somocir 20 .

\section{Estimation of the enzymes}

The test system for measuring the disappearance of acetyglucosamine-6-phosphate contained $0.1 \mu$ mole of substance $0.02 \mathrm{ml}$ of $1 M$ tris-hydroxymethylaminomethame buffer of $\mathrm{pH} 7.7$ and the enzyme.

For glucosamine -6-phosphate the system contained $0.1 \mu$ mole of $N$ glucosamine-6-phosphate, $0.02 \mathrm{ml}$ of $1 M$ tris buffer of $\mathrm{pH} 84,0.02 \mu$ mole of acetylglucosamine-6-phosphate and the enzyme.

For both tests the total volume was $0.05 \mathrm{ml}$ and the incubation time: 15 minutes at $37^{\circ} \mathrm{C} A$ unit was defined as the amount of enzyme causing the disappearance of $25 \%$ of the substrate in 15 minutes.

\section{Preparation of acetyglucosamine-I-phosphate}

This substance was prepared by making trisilver phosphate react with chlorotetraacetylglucasamine. An amorphous bromo derivative was used in many cases until Dr. R. JeAnLoz suggested the use of the chloro compound which can be obtained crystaline.

a-I-chloropentacetyglucosamine. The procedure described by BAKer et al.21 was used with minor modifications. Pentacetylglucoşamine $(6.2 \mathrm{~g})$ prepared with zinc chloride as catalyst as described by Levene 22 was added to a solution obtained by mixing $104 \mathrm{ml}$ of dry ethyl ether saturated with $\mathrm{HCl}$ at ${ }^{\circ} \mathrm{C}$. $18.7 \mathrm{ml}$ 
of acetic acid anhydride and $6 \mathrm{ml}$ of glacial acetic acid. After keeping for $2-3$ days at $0^{\circ} \mathrm{C}$ with occasional shaking, the solid was dissolved. The solution was concentrated in vacuo below $15^{\circ} \mathrm{C}$. The solid was then dissolved in chloroform and treated as described by BAKFr et al.211.

Phosphorylation. $2.9 \mathrm{~g}$ of chloropentaacetylglucosamine were mixed with $1.2 \mathrm{~g}$ of trisilver phosphate 23 and $60 \mathrm{ml}$ of dry benzene. This mixture was heated in a water bath and about $5 \mathrm{ml}$ of the benzene was distilled in order to remove traces of water. After this the heating was continued during 15 minutes, under reflux with shaking. The solid changed from yellow to white and the liquid became brownish.

The mixture was filtered hot through filter aid (celite) and washed with hot benzene.

Hydrolysis. The benzene solution was concentrated to dryness in vacuo and the solid was dissolved in 30 $\mathrm{ml}$ of methanol containing $1.2 \mathrm{ml}$ of $5 \mathrm{~N}$ sulfuric acid. After keeping it for 30 minutes at $379 \mathrm{C}$ the $\mathrm{pH}$ was adjusted to about 8.9 (thymol blue) with $10 \mathrm{~N}$ sodium hydroxide. The $\mathrm{pH}$ was kept alkaline during a few hours by occasional addition of sodium hydroxide. An excess of $50 \%$ barium acetate was added followed by $30 \mathrm{ml}$ of ethyl ether. After leaving it overnight at $5^{\circ} \mathrm{C}$ the mixture was centrifuged. The precipitate was extracted several times with water. The pooled water extracts contained $730 \mu$ moles of labile phosphate.

Purification. A solution containing about $100 \mu \mathrm{mo}-$ les of labile phosphate adjusted to $\mathrm{pH} 8$ was poured onto a column $\left(90 \mathrm{~cm} \times 1.8 \mathrm{~cm}^{2}\right)$ of Dowex 1 of $10 \%$ crosslinkage in the chloride form. Gradient elution was carried out as described by ALM et al. 24 $¥ \mathrm{~A}$

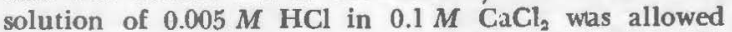
to enter into a $250 \mathrm{ml}$ mixing chamber filled wtih water. The fractions $(5 \mathrm{ml})$ were analysed for acetylglucosamine, after heating for 10 minutes at $1000 \mathrm{C}$ in $0.1 \mathrm{~N}$ acid, and for labile phosphate. Several well separated peaks appeared. The first was free acetylglucosamine. The second had a ratio acetylglucosamine/labile phosphate of 1.7 to 1.9 and consisted mainly of a diester. The third peak which was the largest contained acetylgluçosamine-1-phosphate. Finally a small peak containing unidentified substances appeared.

The fractions corresponding to the third peak were pooled, neutralized with solid $\mathrm{Ca}(\mathrm{OH})_{2}$, filtered, concentrated in vacuo to $1-2 \mathrm{ml}$ and precipitated with 3 volumes of ethanol. If necessary the precipitation was completed by the addition of ethyl ether. The solid was washed several times with ethanol in order to remove the calcium chloride, washed with ethyl ether and dried. Usually the solid was dissolved in a small amount of water, centrifuged and precipitated with ethanol. The yield was about $50 \%$ of the labile phosphate introduced into the column. The ratio acetylglucosamine/phosphate was about 1 and the purity with respect to dry weight was $84 \%$.

The ratatory power was measured on $0.3 \mathrm{ml}$ of solution containing $39 \mu$ moles of he calcium salt and the concentration was checked by phosphate estimation. $[\alpha]_{\mathrm{D}}=+107$.

\section{Preparation of glucosamine-6-phosphate}

Glucosamine was phosphorylated with ATP by n procedure similar to that described by Brown 25 . The fellowing mixture wras incubated at $\mathrm{pH} 8$ : $220 \mu \mathrm{mo}$ - les of glucosamine hydrochloride, $120 \mu$ moles of ATP, sodium salt, $1 \mathrm{ml}$ of $0.1 M$ magnesium sulfate and 1 $\mathrm{m}$ ! of Lebedew juice (prepared by extracting dry yeast with 3 volumes of $0.1 \mathrm{M}$ sodium bicarbonate during 24 hours at $5^{\circ} \mathrm{C}$ ) and water to complete $10 \mathrm{ml}$. After 1 hour at $35^{\circ} \mathrm{C}$ the proteins were coagulated by heating and centrifuged off .

The filtrate was then poured into a column 1.8 $\mathrm{cm}^{2} \times 100 \mathrm{~cm}$ of Dowex-1 $(\times 10)$ in the acetate form. Elution was carried out by a gradient obtained by allowing $0.05 \mathrm{~N}$ acetic acid to flow into a mixing chamber containing $250 \mathrm{ml}$ of water. The fractions were analysed by the method of BuIx'16.

The first fractions contained glucosamine while the phosphiate ester appeared later and was well separated from the former. The last fractions of glucosamine phosphate were slightly contaminated with a substance absorbing at $200 \mathrm{~m} \mu$ and were rejected.

The pooled fractions of glucosamine phosphate were concentrated in vacuo to about $3 \mathrm{ml}$, the $\mathrm{pH}$ was adjusted to 7.2 with barium hydroxide and 3 volumes of ethanol were added. The precipitate was separated, washed with ethanol and ether and dried. The yield was $60-70 \%$ of the glucosamine used, and the product was $80 \%$ pure.

\section{Preparation of $\mathrm{N}$-acetylglucosamine-6-phosphate}

Glucosamine-6-phosphate was treated with acetic anhydride as described by Roseman 26 . The whole reaction mixture including the resin used for the lacetylation was poured on top of a column of Dowex-1 chloride. Displacement from the column was effected gradient-wise as described for acetylglucosamine-1phosphate, but using $0.15 \mathrm{~N}$ HCl. The fractions which gave a ratio total phosphate/acetylglucosamine of one were pooled and the calcium salt was obtained as described for the 1-phosphate. The yield was rather low owing to losses occurring in the precipitation with ethanol.

In some experiments acetylation was carried out at $0^{\circ} \mathrm{G}$ with a slight excess of acetic anhydride in aqueous-pyridine solution. The results were essentially the same as with the other procedure.

\section{N-propionylglucosamine-6-phosphate}

The procedure was the same as for the acetyl derivative but propionic acid anhydride was used.

Purification of the enzyme acting on the 6-phosphates

Pig kidneys obtained frozen from the slaughterhouse yielded active extracts even after several weeks storage in the frozen state. The cortex was homogenized with a blendor in 3 volumes of water and the mixture was centrifuged at 3000 r.p.m. in the cold for 10 minutes (crude extract).

To $80 \mathrm{ml}$ of the crude extract $40 \mathrm{ml}$ of ammonium sulfate solution ( $50 \mathrm{~g}$ percent $\mathrm{w} / \mathrm{v}$ ) were added. After 10 to 15 minutes at $5{ }^{\circ} \mathrm{G}$ the precipitate was centrifuged off and discarded. To $100 \mathrm{ml}$ of the supernatant $20 \mathrm{ml}$ of ammonium sulfate solution were added. The precipitate was separated, dissolved in water and dialysed $4-5$ hours at $5^{\circ} \mathrm{C}$ (Fraction A). Ammonium sulfate solution $(0.2 \mathrm{vol})$ was ladded to the supernatant of the previous step. The precipitate was redissolved and dialysed (Fraction B).

Fraction B was treated with a solution of yeast nucleic acid adjusted to $\mathrm{pH} 7(100 \mathrm{mg}$ per $\mathrm{g}$ of protein). By cautious addition of dilute $\mathbf{H C l}$ followed by contribution, several fnactions were obtained (BI $\mathbf{B}_{2}$, etc.). The precipitates were suspended in water and neutralized. The results are shown in Table I. 
TABLE I

Purification of the enzymes

\begin{tabular}{|c|c|c|c|c|c|c|c|}
\hline \multirow{2}{*}{ Fraction } & \multirow{2}{*}{$\begin{array}{c}\text { Volume } \\
\mathrm{ml}\end{array}$} & \multirow{2}{*}{$\begin{array}{l}\text { Protein } \\
\mathrm{mg} / \mathrm{ml}\end{array}$} & \multicolumn{2}{|c|}{ "Glucosamine-6-P } & \multicolumn{2}{|c|}{ Acetylglucosamine-6-P } & \multirow{2}{*}{ Ratio $A \mid B$} \\
\hline & & & $\begin{array}{c}\text { Units } / m g \\
A\end{array}$ & $\begin{array}{r}\text { Total } \\
\text {. units }\end{array}$ & $\underset{B}{\text { Units } / m g}$ & $\begin{array}{l}\text { Total } \\
\text { units }\end{array}$ & \\
\hline Crude extract & 80 & 53 & 10 & 43000 & 0.75 & 3200 & 13.3 \\
\hline Fraction $\mathrm{A}$ & 5 & 60 & 30 & 9000 & & & \\
\hline Fraction B & 3.5 & 50 & 40 & 7000 & 3.8 & 650 & 10.5 \\
\hline Fraction $\mathbf{B}_{1}$ & 0.23 & 50 & 30 & 350 & & & \\
\hline Fraction $\mathbf{B}_{2}$ & 0.35 & 70 & 75 & 1800 & & & \\
\hline Fraction $\mathbf{B}_{3}$ & 0.30 & 58 & 196 & 3500 & 5.0 & 88 & 39 \\
\hline Fraction $\mathbf{B}_{\mathbf{k}}$ & 0.30 & 46 & 93 & 1300 & & & \\
\hline
\end{tabular}

\section{RESULTS}

\section{Prosperties of acetylglucosamine-I-phosphate}

The molecular rotation of I-phospho sugars is known to be comparable to that of the methylglycosides ( $c f$. LELOIR ${ }^{27}$ ). For methyl$\mathrm{N}$-acetylglucosaminide the values given by Neuberger and Pitt Rivers ${ }^{28}$ are $+24,675$ for the $\alpha$ - and 10.105 for the $\beta$-anomer. The acetylglucosamine-1-phosphate prepared as described here gave a value of $+36,000$ so that it is the $\alpha$-anomer. The product has been used by Dr. REISsIG ${ }^{9}$ in a study of the phosphoacetylglucosaminemutase of Neurospora and several preparations were found to be over $90 \%$ converred into the 6 phosphate. The substances does not reduce sugar reagents and gives the Morgan and Elson reaction only after acid hydrolysis.

\section{TABLE II}

Acid hydrolysis of acetylglucosamine-1-phosphate

\begin{tabular}{r|cc|cc}
\hline \multirow{2}{*}{$\begin{array}{c}\text { Time } \\
\text { (hours) }\end{array}$} & Acetylglucosamine-1-phosphate & \multicolumn{2}{|c}{ Glucose-1 -phosphate } \\
\cline { 2 - 2 } \cline { 5 - 5 } $\begin{array}{c}\text { Percent } \\
\text { hydrolysis }\end{array}$ & $103 \mathrm{~K}$ & $\begin{array}{c}\text { Percent } \\
\text { hydrolysis }\end{array}$ & $103 \mathrm{~K}$ \\
\hline 1 & 26.6 & 2.2 & 37.8 & 3.3 \\
2 & 41.0 & 1.9 & 60.5 & 3.4 \\
3 & 58.2 & 1.7 & 76.2 & 3.4 \\
4 & 58.2 & 1.6 & 79.0 & 2.8 \\
5 & 67.8 & 1.7 & 87.0 & 2.9 \\
6 & 75.4 & 1.7 & 92.3 & 3.1 \\
18 & 100.0 & - & 100.0 & - \\
& & 1.8 & & 3.1 \\
\hline
\end{tabular}

Inorganic phosphate was estimated after incubating the samples at $378 \mathrm{C}$ in $1 \mathrm{~N}$ sulfuric acid. The fermula used was: $K=\left(t_{2}-t_{1}\right)^{-1} \log _{\perp 0}\left(100-x_{1}\right) /(100$ $-x_{2}$ ). The time was taken in minutes. No detectable amounts of glucosamine were formed.
The results of acid hydrolysis in I $N$ acid at $37^{\circ} \mathrm{C}$ are shown in Table II. It may be observed that the acetylglucosamine ester is slightly more stable than that of glucose. However it is much more labile than glucosamine-1-phosphate $^{29}$ and galactosamine - I-phosphate ${ }^{30}$

\section{The action of enzymes on acetylglucosamine- I-phosphate}

On incubation of the 1-phospho ester with crude kidney or liver extracts it was observed that a part was converted to free acetylglucosamine while another part was transformed into substances which did not give the Morgan and Elson test even after acid hydrolysis. The formation of acetylglucosamine-6-phosphate as an intermediate in this reaction could be detected only by purification of the crude extracts or as shown in Table III by the use of an inhibitor. Such a selective inhibition of acetylglucosamine-6-phosphatedisappearance could be obtained with acetate without affecting the activity on the Iphosphate. Under these conditions about half of the decrease in acetylglucosamine-I-phosphate could be accounted for by the increase in the 6-phosphate. These results are shown in Table III. Other test were carried out with an enzyme prepared by a method based on the first steps of the purification of phosphoglucomutase as described by NaJJAR ${ }^{\text {in }}$. The results in Table IV show that the process is activited by magnesium ions and slightly activated by glucose disphosphate. In that experiment the results of the estimation were checked with a specific enzyme method for acetylglucosamine-6-phosphate. In the other experiments rat muscle or liver extracts were found to catalyse the conversion of the I-to 6-phosphate at similar rates. 
The actiom of enzymes en the 6-phosphates

Cirude preparations of pig kidney catalyse the disappearance of acetylglucosamine- $(5-$ phosphate. Glucosamine-6-phosphate also disappears provided small amounts of acetylglucosamine-6-phosphate are also added. As shown in Table I both activities may be detected after some purification but the ratio of the two varies from 13 to 39. The action on the non-acetylated substance was always higher than on the acetylated.

T. ABLE III

The action of kidney extracts on acethlghosamine-1-phosphate

\begin{tabular}{|c|c|c|}
\hline & \multicolumn{2}{|r|}{$\perp m$ mirromoles } \\
\hline & No & acetute With acelate \\
\hline $\begin{array}{l}\text { lectylglucosamine-1-phosphate } \\
\text { irce acetylglucosamine (b) }\end{array}$ & & $\begin{array}{r}-0.053-0.01 \% \\
+0.015+0.017\end{array}$ \\
\hline Acctylg]ucosamine-6-phosphate & $(a-b)$ & $+0.002+0.033$ \\
\hline
\end{tabular}

Incubation of $0.05 \mathrm{ml}$ of crute hidney extracts (1 vol of water used) $0.01 \mathrm{ml}$ of $0.36 \mathrm{M}$ glyoerophosphate buffer $\mathrm{pH} 7.4,0.01 \mathrm{ml}$ of $1, M$ socintm acetate $(\mathrm{pH}$ $7.4)$ and 0.08 mole of acctylglucosamine-1-phosphate listimations were as follow's: (a) direct estimation of acetylhexosamine, (b) same in the supernatant obtaincl after precipitation with rine sulfate and barium hydroxide, (c) as (a) but after removing protein with 5 " trichloracetic acid and heating 10 minutes at 1000 (:

\section{TABLE IV}

The comiersion of acelylgherstmin 1-phosphate to the G-phospitite

\begin{tabular}{lcc}
\hline & \multicolumn{3}{c}{$\begin{array}{c}\text { Umoles of } \\
\text { acelylghurosamme-6-phosphate }\end{array}$} \\
\hline $\begin{array}{c}\text { Chemical } \\
\text { melhod }\end{array}$ & $\begin{array}{c}\text { Enzymir } \\
\text { methor }\end{array}$ \\
\hline Complete system & 0.089 & 0.08 \\
No glucose diphosphate & 19.076 & - \\
No magnesium & 0.045 & -
\end{tabular}

The complete system contained rol $\mathrm{ml}$ of $0.36 \mathrm{M}$ glvcerophosphate buffer $\mathrm{pH} 7.4,0.005 \mathrm{~m} /$ of saturated solution of 8'-hydroxyquinoline: $0.01 \mathrm{ml}$. of $0.1 \mathrm{M}$ magnesium chloride, 0.ros $\mu$ mole of glucose diphosphate, 0.17 mole of acetylglucosamine-1-phosphate and cnzyme. Incubated 1 hour at $37^{\circ} \mathrm{C}$, total volume (i.08 $\mathrm{ml}$. The enzyme was prewarel from pig kidney by adjusting the crude extract io pll :5, precipitating the supernatant with 0.65 saturaled ammonium sulfate and dialysing. Estimations by chemical method $a^{*}$ in Table III. For the enzymic nethod the activating power on glucosamine-6-phosphit: rlisappearance was compared with a standar l of actylglucosamine6-phosphate using a purified cozrme.
The pH optima are shown in Fig. I.

Free glucosamine or acetylglucosamine were not arted upon by the enzyme preparations.

Many experiments we carried out in order to detect a cofactor. The enzyme was submitted to prolonged dialysis against ethylenediaminetetracetate solutions, to precipation with $0.1 \mathrm{~N}$ acid from ammonium sulfate solutions and to treatment with anion exchange resins but no organic or inorganic ion requiriment could be detected.

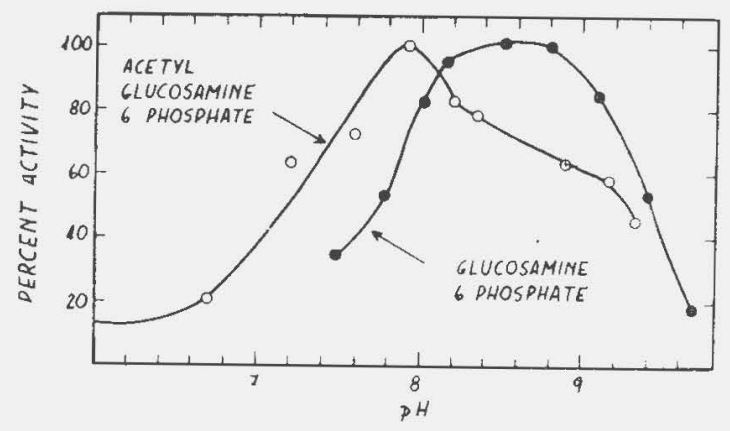

Fir: 1. - pH optima. Condtions as described for test systcm with Tris $\mathrm{HCl}$ and Tris-maleate, buffers prepared as rlescribed by Gomore 35 . The $\mathrm{pH}$ was checked in aliquots with a glas, electrode.

\section{The action of acetate}

As shown in Table $V$ acetate nearly sup. presses acetylglucosamine-6-phosphate disappearance while it does not alfect appreciably that of glucosamine-6-phosphate. The results with propianate or butyrate were similar to those obtained with acetate while formate showed no action.

TIBLE V

The action of arelut.

\begin{tabular}{|c|c|c|}
\hline substrale & Addition & $\begin{array}{l}\text { Substrate } \\
(+ \text { mote) }\end{array}$ \\
\hline Acetylglucosamina-6-phosphate & none & 0.169 \\
\hline Acctylglucosamine-6 phosphate & acietate & 0.02 \\
\hline Glucosaminc-6-phosphate & none & 0.1 .1 \\
\hline Glucosaminc-6i-phosphate & acetate & 0.14 \\
\hline
\end{tabular}

Conclitions as described for test systom with $0.2, \mathrm{M}$ acctatc.

The action of acetylghucomasine-6-phosphate on glucomasine phosphate disappearance

As shown in Fig. 2 glucosamine-6-phosphate is not transformed in the absence of acetyl- 
glucomasine-6-phosphate. The effect of the latter is catalytic since $0.009 \mu$ mole can produce the disappearance of $0.05 \mu$ mole of glu= cosamine-6-phosphate. Many substances hąve been tested as possible substitutes for acetylglucosamine-6-phosphate. The results were negative with: acetylglucosamine, acetamide, UDP-acetylglucosamine, acetate, acetate plusammonia, hexose-6-phosphates, acetylglycine, acetyltriptophane, acetylcholine, pyruvate, citrate and $\alpha$-Ketoglutarate. With acetylglucosamine-1-phosphate some activation was obtained using crude extracts but none with purified preparations.

Only one substance was found to have the activity of $\mathrm{N}$-acetylglucosamine-6-phosphate and that was N-propionylglucosamine-6- phosphate. This ester was also found to disappear on incubation with the ensyme. The quantitative results were very similar with the acetyl and propionyl derivatives. te the reaction was faster so that the interference of traces of isomerase was smaller. Fig. 3 shows the result of such an experiment. Glucosamine-6-phosphate disappeared rapidly with a concomitant rise in the fructose values and in the sum fructose- 6 plus glucose6-phosphate as deteminated whit glucose-6phosphate dehydrogenase plus isomerase and TPN. After some minutes the fructose values decreased slowly, as was expected, owing to the presence of isomerase in the enzyme preparation.

In another experiment with a preparation that was nearly free from isomerase the results were as follows:

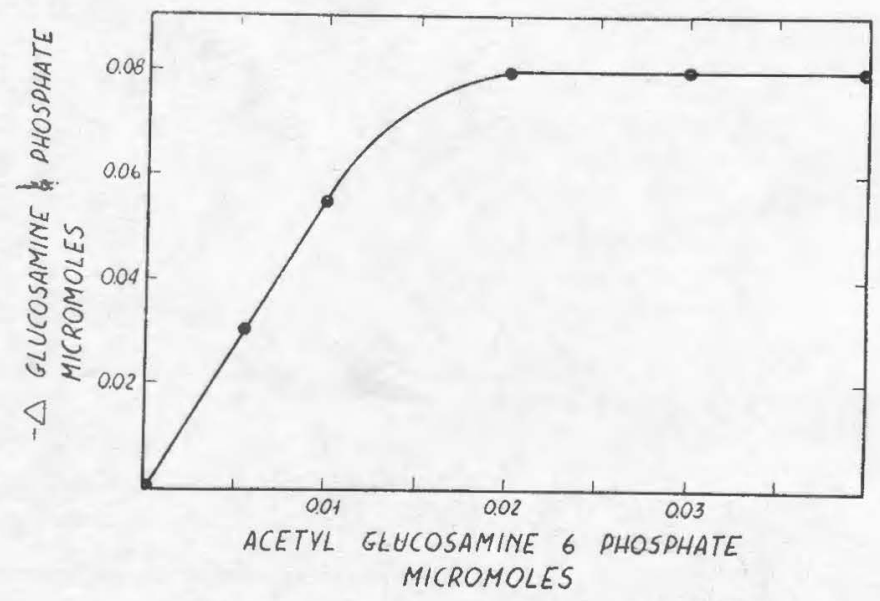

Fig. 2. - The action of acetylglucosamine-6-phosphate on glucosamipe-6-phosphate disappearance. Conditions as described for test system, but witl: variable amounts of acetyl glucosamine-6-phosphate.

\section{The reaction products}

Analysis by paper chromatography of the prołucts obtained from acetylglucosamine-6phosphate with a crude enzyme preparation, and after treatment with phosphatase, revealed the presence of glucose, fructose and in some cases of a substance reacting like heptulose ${ }^{32}$. Hexose phosphate isomerase was dificult to remove from the preparations but in one case a quantitative accumulation of fructose ester from acetylglucosamine-6-phosphate was obtained. With glucosamine-6-phosphate as substra-
It seems clear therefore that the primary reaction products are Fructose-6-phosphate and ammonia.

\section{Reversible formation of glucosamine-6-phos- phate}

The incubation of fructose-6-phosphate and ammonia with the enzyme and small amounts of acetylgiucosamine-6-phosphate led to a definite increase in "glucosamine" as estimated by the BuIx method. No increase ocurred 


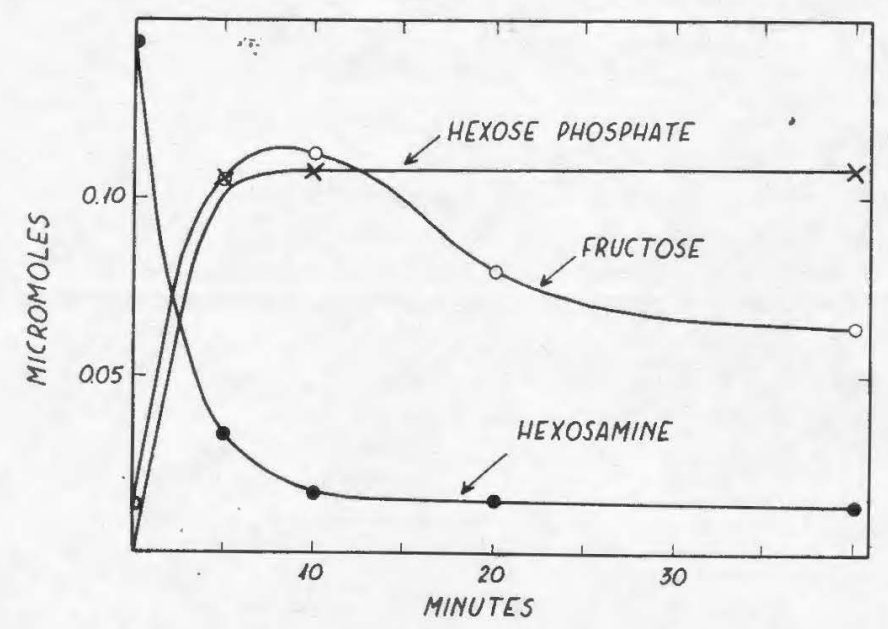

Fig. 3. - Chemical changes during the transformation of gldcosamine-6-phosphate. The reaction mixture contanied $0.15 \mu$ mole of glucosamine- 6 phosphate, $0.04 \mu$ mole of acetylglucosamine-6-phosphate, $0.04 \mathrm{ml}$ of $1 \mathrm{M}$ tris buffer of $\mathrm{pH} 8.4$ and $0.04 \mathrm{ml}$ of enzyme precipitated twice with nucleic acid. Total volume $0.1 \mathrm{ml}$. Temperature: $37{ }^{\circ} \mathrm{C}$.

if the ammonia, fructose phosphate or acetylglucosamine-6-phosphate were omitted or if ammonia was substituted by glutamine or asparagine. The results were also negative if free fructose, glucose, xylose or ribose were added instead of fructose-6-phosphate. A representative experiment is shown in Table VI. The - $^{-1}$ se results were taken as an indication that the reaction can be reversed and measurements of the equilibrium constant were carried out, starting with known reaction mixtures and estimating the changes in glucosamine phosphate produced by the enzyme. One suchs experiment is shown in Table VII. The values obtained for $K$ in moles/liter varied from 0.12 to 0.18 . In other experiments

\section{TABLE VI}

Synthesis of glucosamine-6-phosphate

\begin{tabular}{lc}
\hline & $\begin{array}{c}\text { "Glucosamine" formed } \\
\mu \text { moles }\end{array}$ \\
\hline Complete system & 0.014 \\
No ammonium sulfate & 0.002 \\
No acetylglucosamine-6-phosphate & 0.002 \\
Glutamine instead of ammonium sulfate & $\mathbf{0 . 0 0 2}$ \\
Asparagine instead of ammonium suifate & 0.002 \\
\hline
\end{tabular}

The complete system contained: $0.5 \mu$ mole of fructose-6-phosphate $1.5 \mu$ moles of ammonium sulfate, $0.02 \mu$ mole of acetylglucosamine-6-phosphate, 001 $\mathrm{ml}$ of $2 M$ tris buffer and $0.27 \mathrm{mg}$ of enzyme preparation ( $B_{1}$ Table $\left.\mathrm{I}\right)$. Total volume $0.05 \mathrm{ml}, 30 \mathrm{minu}$ tes at $379 \mathrm{C}$. The glucosamine values obtained on samples at $t_{0}$ were substrated. the results were more variable $(0.04$ to 0.19$)$. Owing to analytical errors and to some uncertainly regarding the true molarity of the substrates perhaps the results should only be taken as indicating the order of magnitude of $K$. Thus the fructose-phosphate concentration was calculated assuming that isomerase converted it into the equilibrum mixture which contains $66 \%$ of glucose-6-phosphate. However, it was clear in all the experiments that similar values for $K$ are obtained in the forwand and in the reverse reaction.

TABLE VII

Equilibrium constant

\begin{tabular}{lll|c|c}
\hline \multicolumn{2}{c|}{ Substances added $(\mu$ moles $)$} & $\Delta$ & $\mathcal{K}$ \\
\hline Fructose-6-P & Ammonia & Glucosamine-6-P & Slucosamine & \\
\hline 0.326 & 1.0 & 0 & +0.0128 & 0.16 \\
0.326 & 1.0 & 0.0085 & +0.0058 & 0.15 \\
0.326 & 1.0 & 0.0170 & +0.0016 & 0.12 \\
0.163 & 2.0 & 0 & +0.011 & 0.18 \\
0.163 & 2.0 & 0.0085 & +0.0057 & 0.15 \\
0.163 & 2.0 & 0.0170 & -0.002 & 0.16 \\
\hline
\end{tabular}

Incubation of fructose-6-phosphate with ammonium sulfate and glucosamine-6-phosphate; 0.02 ml-tris buffer $1 \mathrm{M} \mathrm{pH} \mathrm{8.4;0.02} \mathrm{mg} \mathrm{enzyme} \mathrm{(} B_{3}$, Table I) final volume $0.05 \mathrm{ml} ., 10 \mathrm{~min}$ at $379 \mathrm{C}, K=\left[\mathrm{NH}_{2}\right]$ [Tructose-6-phosphate] / [glucosamine-6-phosphate] in moles/liter. The concentration of fructose- 6 -phosphate was taken as $1 / 3$ of theorical amount in order to correct for the presence of isomerase. 
TABLEVIII

The action of extracts from different organs on glucosamine-6-phosphate

\begin{tabular}{lc}
\hline Organ & $\begin{array}{c}\text { Activity } \\
\text { units } / m g\end{array}$ \\
\hline Kidnetein
\end{tabular}

The rat organs were homogenized in 2 vol. of water at $0{ }^{\circ} \mathrm{C}$ and centrifuged. Test with glucosamine-6-phosphate were carried out as described for the test system.

\section{Distribution of the glucosamine-6-phosphate enzyme $(s)$}

As shown in Table VIII, kidney is the richest source of enzyme, followed by brain, intestine, liver and lung. No activity was detected in heart or in yeast. The same extracts were tested for the rate of the reverse reaction starting with fructose phosphate and ammonia and essentially similar results were obtained.

\section{DISCUSSION}

The first step in the transformation of acetylglucosamine-I-phosphate catalysed by animal tissues has been found to be:

acetylglucosamine-1-phosphate $\rightleftharpoons$

acetylglucosamine-6-phosphate

It remains to be decided whether the change is brought about by phosphogluco-mutase or by a specific enzyme. Evidence showing that two enzymes are present in Neurospora extracts has been obtained by ReIssig ${ }^{9}$ who separated some fractions which were more active on the acetylglucosamine ester than on glucose pliosphate, and other fractions which behaved inversely. $\mathrm{He}$ also detected phosphoacetylglucosaminemutase activity in a highly puified rabbit muscle phosphoglucomutase.

As to the transformations of the 6-esters the reported facts can be rationalized by the following reactions:
Other formulations involving a cofactor can be written but no supporting evidence was found despite many efforts. Reactions (I) + (3) would be responsible for the disappearance of acetylglucosamine-6-phosphate. Acetate would inhibit reaction (3)-Glucosamine -6-phosphate would be transformed through reactions (I) $+(2)$ and thus the necessity of catalytic amounts of acetylglucosamine-6phosphate would be explained.

As to the nature of the substance $X$ it is attractive to suppose that it is $\mathrm{N}$-acetylfructosylamine-phosphate (II). In this case reaction (I) would be similar to an Amadori rearrangement, i.e. the conversion of an aldose (I) to a ketose (II) derivative. After transacetylation (Reaction (2)) the product would be fructosylamine phosphate, which is presumably an unstable substance that descomposes into fructose phosphate and ammonia. It may be mentioned that fructosylamine does not appear to be stable since it has never been prepared and when fructose reacts with ammonia it is the isomer, glucosamine, which has been obtained (HEYNS AND MEINECKE ${ }^{\circledR 3}$, CARSoN $\left.{ }^{84}\right)$.

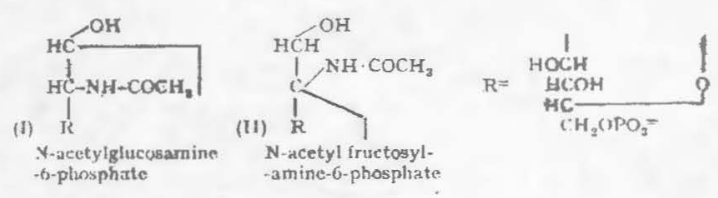

\section{ACKNOWLEDGEMENT}

Our thanks are due to Dr. E. CABIB for a preparation of glucose dehydrogenase, to Dr. E. RACKER for suggesting nucleic acid precipitation as a means of removing isomerase and to MARgrete OxHoLM for technical assistance.

\section{SUMMARY}

The chemical synthesis of $\alpha$-acetylglucosamine-I-phosphate and some of its properties are described. From kidney or liver, enzymes have been obtained which

$$
\begin{aligned}
\text { acetylglucosamine-6-1' } & \rightleftharpoons \mathrm{X} \\
\text { glucosamine-6-P }+\mathrm{X} & \rightleftharpoons \text { acetylglucosamine-6-P }+ \text { fructose-6 P }+\mathrm{NH}_{3} \\
\mathrm{X} & \rightarrow \text { fructase-6-P }+\mathrm{NH}_{2}+\text { acetate }
\end{aligned}
$$


catalyse the following reactions:

$a$-acetylglucosamine-I-phosphate $\rightleftharpoons$ acetylglucosamine-6-phosphate

N-acetylglucosarsine-6-phosphate $\rightleftharpoons$ fructose-6phosphate $+\mathrm{NH}_{3}+$ acetate

$$
\text { glucosamine-6-phosphate } \rightleftharpoons \text { fructose-6-phosphate }+\mathrm{NH}_{3}
$$

Reaction (1) was found to be aclivated by magnesium ions. The enzyme(s) responsible for reactions (2) and (3) were purified and it was observed that

(3) requires catalytic amounts of $\mathrm{N}$-acetylglucosamine-
1 E. Cabib, L. F., Lelotr ayd C. E. Cardini, J. Biol. Chem., 203 (1953) 1055.

2 R. B. Hulbirt and V. R. Potter, J. Biol. Chem., 209 (1954) I.

3 H. Schmitz, V. T. Potter, R. B. Hulbert and D. WhrTe, Cancer Research, 14 (1954/66).

4 H. G. Pontis, J. Biol. Chem, 216 (1955) 195.

5 E. E. B. Smith and G. T. Mills, Birchim. Biophys, Acta, 13 (1954) 386.

G J. L. Strominger, Biochim. Biophy. Acta, 17 (1955) 283.

7 C. F. CORI, S. P. COLOWICK AND G. T. CORI $J$. Biol. Chem., 121 (1937) 465.

8 L. F. Letoir and C. E. Cardini, Biochim. Biophys. Acta, 12 (1953) 15.

9 J. L. RFissig. J. Biol. Chem. (in press).

10 D. H. Brown, Biochim. Biophys. Acta, 16 (1955) 429.

11 A. Dorfman, Pharmacol. Rev., 7 (1955) I.

12 P. W. Kent AND M. W. Whitehouse, Biochemistry of the Aminosugars, Butterworth's Scientific Publications, London, 1955.

13 C. H. Fiskf. and Y. Subbarow, J. Biol. Chem., 66 (1925) 375.

14. M. Kunitz and M. McDonald, J. Gen. Physiol, 29 (1945) 393.

15 J. H. Roe and N. M. Papadopoulos, J. Biol. Chem., 210 (1954) 703.

16 G. Blix, Acta Chem. Scand., 2 (1948) 467.

17 E. J. Conway, Micro--Diffusion Anolysis and Volumetric Error, Crosby, Lockwuori and Son, Ltd., Loadon, 1939. 6-phosphate (or of the $\mathrm{N}$-propionyl derivative) and that it is reversible. The possible mechanism of the reactions is discussed.
18 J. L. Rfissig, J. L. Strominger AND L. F. Leloir, J. Biol. Chem., 217 (1955) 959.

19 S. Roseman and J. Ludowiec, I. Am. Chem. Soc., 76 (1954) 301.

20 M. Sомосчі, J. Biol. Chem., 160 (1945) 69.

21 B. R. Baker, J. P. Joseph, R. E. Sctiaub and J. H. Williams, 7 . Org. Chem., 19 (1954) 1786.

22 P. A. LeVent, Hexosamines and Mucoproteins, Longmans, Green and Company, London, 1925.

23 Biochemical Preparation, John Wiley \& Sons. New York, Vol. I, 1949, p. 35.

$2 t$ R. S. Alm, R. J. P. Williams and A. Tiselius, Acla Chem. Scand., 6 (1952) 826.

25 D. H. Brown, Biochim. Biophys, Acta, 7 (1951) 487.

26 S. Roseman, Federation Proc., 13 (1954) 283.

27 L. F. LELoIr, Fortschr. Chem. org. Naturstoffe, 8 (1951) 48.

28 A. Neubfrcer and R. Pitt Riveri, J. Chem. Soc., (1939) 122.

29) D. H. Brown, J. Biol. Chem. 204 (1953) 877.

30 C. E. Cardini and L. F. Leloir, Arch. Biochem. Biophys., 45 (1952) 55.

31 V. A. NajJar, J. Biol. Chem., 175 (1948) 281.

3? R. Kievstrand and A. Nordal, Acta Chem. Scand., 4 (1950) 1320.

33 K. Heyns and K. H. Meinecke, Chem, Ber., 86 (1953) 1453.

34 J. F. Carson, J. Am. Chem. Soc., 77 (1955) 1881.

35 G. Gomori in S. P. Colowick ANd Kaplan, Methods in Enzymology, Academic Press, Inc., New York, 1955, p. 138. 